\title{
THE PHILOSOPHIA CHRISTI, ITS ECHOES AND ITS REPERCUSSIONS ON VIRTUE AND NOBILITY
}

\author{
Han van Ruler
}

The way to virtue, Erasmus says in his Enchiridion militis Christiani of 1504, depends on two things: first, to "know yourself"; secondly, to act "not according to the passions, but the dictates of reason". Nothing is harder, Erasmus agrees, but then "no reward is greater". For it was with a view to higher pleasures ahead that actual hardships should be surmounted. As Plato had written: "whatever is excellent is also hard".

The fact that, in his posthumous Ethics of 1677, Benedictus de Spinoza would likewise claim that "all things excellent are as difficult as they are rare", might be read as an indication of the continued presence of humanist training. It is actually much more than that. In Spinoza, as in Erasmus, what is considered difficult is the individual's ability to achieve a lasting type of moral transformation. And in Spinoza, too, the promise is made that whoever succeeds in this will find felicity. Both points form part of a particular combination of religious and philosophical discourse that dominated moral philosophy throughout the sixteenth and seventeenth centuries. Though this early-modern intellectual attitude may be too broad for Erasmus' Philosophia Christi to be regarded as its archetype, this article will nevertheless take Erasmus' view on moral philosophy as its starting-point, in order to point out similarities with a number of other early-modern systems of morality that combined ancient philosophical norms with a fundamentally religious conception of mental transformation. It is my hope that, by presenting this broader picture of the early-modern amalgamation of reason and faith, we may get a better idea of the alternative positions that radically broke with it. In this paper, I shall offer the views of Blaise Pascal and Thomas Hobbes as two such alternatives, and argue that, since neither of these latter thinkers formulated their ideas along the lines of ancient philosophical schools, it was the broader early-modern conception of morality itself that should be seen as the necessary background for their views.

${ }^{1}$ Desiderius Erasmus Roterodamus, Enchiridion militis Christiani, in Ausgewählte Werke, ed. H. and A. Holborn, vol. 1 (Munich, 1933, 1964²), p. 46. Translation from The Enchiridion of Erasmus, ed., transl. R. Himelick (Bloomington, 1963), pp. 70-71.

${ }^{2}$ Spinoza, Ethica V, Prop. 42, Scholium in Opera, ed. C. Gebhardt (Heidelberg, 1925), vol. 2, p. 308; A Spinoza Reader: The Ethics and Other Works, ed., transl. E. Curley (Princeton, 1994), p. 265.

(C) HAN VAN RULER, 2009 | DOI:10.1163/9789047429753_015

This is an open access chapter distributed under the terms of the CC BY 4.0 license. 
The fact that there was such a thing as an early-modern amalgamation of reason and faith - and that this was in fact the broadly accepted position - indicates that it is by no means evident that early-modern philosophical debates may be explained on the basis of a choice between the acceptance or the rejection of pagan thought. Though few historians will readily subscribe to the thesis that Renaissance moral philosophy witnessed a rise of paganism that would triumph in the Enlightenment, or that the "making of modernity" was the outcome of a battle between philosophy and religion, it is rare that such popular theses are challenged. Yet crucial turning points in the history of Western morality, such as Pascal's "anti-humanism" and Hobbes' rejection of the ancient quest for mental tranquillity, were both closely related to theological ways of thinking and, if anything, fiercely opposed to the pagan tradition. If we are to understand the significance of these dissenting viewpoints, it will be necessary to evoke the background murmur against which they were heard.

Let us start out, however, by considering the humanist context itself and therefrom distilling some of the relevant aspects of Erasmus' Philosophia Christi - such as the compatibility of philosophy and religion and the notion of man's supreme good - by contrasting it with a form of humanism that was not of Erasmus' type.

\section{THE AMALGAMATION OF REASON AND FAITH}

If many a medieval, Renaissance or even seventeenth-century writer might have accepted the idea that moral excellence was a subject philosophy and religion shared, this does not mean that all would fit the "Erasmian" scheme. One of the most basic assumptions of all humanist thought was that classical examples might merge with the example of Christ. Rudolph Agricola, to take an example from Erasmus' immediate intellectual background, had stated that, with regard to ethics,

you must not only look to what philosophers have written on this subject (philosophers such as Aristotle, Cicero, Seneca, or any others that either wrote in Latin or were translated into an acceptable Latin). You must also seek it from historians and poets and orators. They do not actually teach, but by praising good deeds and criticising wrongdoing, they do so in effect, and most effectively: the examples they present mirror what is right or wrong. ${ }^{3}$

Erasmus mentions the same philosophers where he advises his Prince on the better kind of literature: Seneca, Aristotle and Cicero. He adds Plutarch as the best example in questions of politics and political biography, and Plato, who

\footnotetext{
${ }^{3}$ Rudolphus Agricola, De formando studiis (= Letter to Jacob Barbireau of 7 June 1484), in: Lvcvbrationes aliqvot lectv dignissimae (Cologne: Ioannes Gymnicus, 1539), facs. reprint Opuscula orationes epistulae (Frankfurt am Main, 1975), p. 194. For a critical edition and translation, see Rudolph Agricola, Letters, ed. A. van der Laan and F. Akkerman (Assen and Tempe, 2002), pp. 204-205.
} 
offers "the purer message" on the subject of political office. Erasmus is less enthusiastic than Agricola on the possibility of drawing the right examples from historians, poets and orators, but still agrees that their work offers much that may be used as a guide in questions of virtue and vice. Even the bad examples are useful! Promoting his own De copia of 1512 in The Education of the Christian Prince, Erasmus all but says that the reader may stick to this secondary work, where the right selection of ancient non-philosophical sources may already be found. ${ }^{4}$

Both Agricola and Erasmus, moreover, explicitly mention Scripture as the truer fount of moral knowledge. As Agricola argues, one has to take ethics "a step further, and look at Holy Writ", since "[everything] handed down by others contains mistaken ideas of one kind or another". 5 Erasmus likewise upholds the supremacy of Scripture:

if any tutor wants my advice, as soon as the boy [i.e., the future Prince (HvR)] has a grasp of language he should present the proverbs of Solomon, Ecclesiasticus, and the Book of Wisdom. [...] Next the Gospels; and here it is very important in what way you kindle love of the author and the work in the boy's mind. ${ }^{6}$

Yet despite such obvious similarities where it comes to deriving moral lessons from the classics and using Holy Writ in moral education, Erasmus' and Agricola's positions differed in important respects. Although they agreed on the relative status of pagan sources, they did not agree on the ultimate aim of studying them. For Agricola, any subject would bind the orator to the accepted facts and presuppositions the specific subject was thought to have. In the case of moral philosophy, one might focus on the philosophical criteria of merit and moral worth. These, however, are themselves thought to be more or less selfevident. It only takes a rhetorical re-enactment of specific literary or Biblical examples to bring about a recognition of moral clues on the side of one's audience. Agricola's discussion of the story of Lucretia in the famous letter De formando studio is a fine example of this. ${ }^{7}$ The public will be able to grasp the conclusions themselves.

Erasmus, on the other hand, did not share Agricola's confidence that moral growth might be won by a mere application of dialectical techniques. Indeed, in contrast to the latter's more or less ad hoc way of applying dialectics to ethics, Erasmus' moral theory is of an altogether more programmatic nature. The phrase Philosophia Christi itself links up with the idea that, even though they may differ in "quality" and in detail, the aims of philosophy and religion are, or

${ }^{4}$ Desiderius Erasmus, Institutio principis Christiani, ed. O. Herding, in Opera omnia Desiderii Erasmi Roterodami, series IV, vol. 1 (Amsterdam, 1974), p. 181. Quotation from Erasmus, The Education of a Christian Prince, transl. M. Cheshire and M. J. Heath, ed. L. Jardine (Cambridge, 1997), p. 62.

${ }^{5}$ Agricola (as in n. 3), De formando studiis, p. 194; Letters, pp. 205-207.

${ }^{6}$ Erasmus (as in n. 4), Institutio principis Christiani, p. 180; The Education of a Christian Prince, p. 61.

${ }^{7}$ Agricola (as in n. 3), De formando studiis, p. 198; Letters, pp. 214-215. 
at least should be, the same - not in the sense that they offer similar literary examples (which they do), but in the sense that the New Testament message is thought to embody the essence of an ideal philosophy. Many of Erasmus' references to ancient examples and traditions are made with a view to convincing the reader that if pagans were as wise as they seem to have been from their writings, and if they had such high moral standards, then Christians should be all the wiser. A very pointed version of this idea is found in The Education of a Christian Prince: "Being a philosopher", Erasmus argues, "is in practice the same as being a Christian; only the terminology is different". 8

The philosophical side of the equation brings with it a host of anthropological considerations that are presumed to be present, or at least to be implied, in the Biblical text. Purporting to explain in a concise way the New Testament theme of the flesh and the spirit in the Enchiridion, Erasmus for instance equates this Biblical vision of man with a Platonic theory of metaphysical dualism. Others have held such identifications to be characteristic more exclusively of Augustinian and Cartesian traditions. As the Canadian philosopher Charles Taylor has argued, in these latter schools

[the] Pauline opposition of spirit and flesh is repeatedly being pulled out of its hinges and aligned with the Platonic-derived opposition between the immaterial and the bodily.

Taylor seems to imply that the two should be distinguished. Yet if there are indeed differences between the Biblical and philosophical types of dualism, Erasmus certainly did not acknowledge them. Nor did he ever hesitate to interpret St. Paul's message in philosophical terms. On the contrary, "why mention one or two such passages?", he argues:

Paul is engrossed in this point, that we should spurn the strife-ridden flesh and be firm in the spirit, the begetter of love and liberty. On the one hand, the flesh, bondage, unrest, contention are inseparable companions; on the other, the spirit, peace, love, freedom. This is what the Apostle teaches everywhere. ${ }^{10}$

It is true that there is a strange ambiguity with respect to the interpretation of the Pauline theme in Erasmus. In the purely theological sphere, the distinction between flesh and spirit could well serve to distinguish allegory from literalism, clearing the way for an allegorical reading of Scripture. Especially in the context of favourite subjects such as ritualism, Erasmus made ample use of this possibility and contrasted the letter of the Biblical text with its evangelical message. We thus find samples of anti-legalist next to anti-ritualist rhetoric in the Enchiridion, all concerned with a lenient notion of Christian charity that is

\footnotetext{
${ }^{8}$ Erasmus (as in n. 4), Institutio principis Christiani, p. 145; The Education of a Christian Prince, p. 15.

${ }^{9}$ C. Taylor, Sources of the Self: The Making of the Modern Identity (Cambridge, 1989), p. 220.

${ }^{10}$ Erasmus (as in n. 1), Enchiridion, p. 82; The Enchiridion, p. 121.
} 
phrased exclusively in terms of moral fairness and provides a rather abstract interpretation of what is "carnal" and what is "spiritual". A telling illustration of this is Erasmus' portrayal of the good, the neutral, and the evil judge:

Suppose a judge gives short shrift to malefactors; he thinks of himself as a stern and incorruptible man. But would you care to look into him? If he is indulging his own disposition and yielding to a certain innate harshness, if he feels no distress of mind, but perhaps even a kind of pleasure, even though he never leaves off being a judge, then he should not be too highly pleased with himself. What he does is, morally, on a middle ground. If he is misusing the law for a private grudge or out of cupidity, then what he does is carnal and he is committing murder. But if he feels sharp grief of mind in being forced to destroy a man he would have preferred to reform and save, if he inflicts a merited punishment in the spirit of a father ordering his dearest son to be cut off and burned, then his action stems from the spiritual part. ${ }^{11}$

A selfish abuse of power is what is here defined as "carnal", and though the example does not entirely make clear in what way the bad judge "misuses" the law, the judges' respective positions are distinguished on the basis of their respective intentions instead of their decisions. Thus by emphasising the importance of mental intentions versus literal commandments, the example neatly affirms the difference between the spirit of the law and its literal formulation.

In other contexts, however, allegory and spiritual meaning form no part of Erasmus' explanations and a "strong", literal, interpretation of carnality takes the place of the "weaker" interpretation in terms of moral fairness. To be sure, the line is not even very sharp in the example of the judge, where Origen's tripartite division of man into spirit, soul and flesh, already crops up in a more literal way through the use of such terms as indulgere and cupiditas. ${ }^{12}$ In other contexts, this alternative interpretation presents itself even more sharply, in such a way that the theme of the flesh and the spirit is wholly disconnected from questions of allegory and is linked instead to a philosophy of man that distinguishes free mental attitudes from those tainted by bodily drives.

Erasmus in fact often literally interprets the Pauline theme as a distinction between the mental and the physical. It is, moreover, in this way that he links Christian moral demands to pagan philosophical objectives. With pagan philosophical ideas substantiating Biblical truth, the Enchiridion time and again affirms the idea that there is no other aspect of human life that opposes Christian piety as much as carnality and the lures of the flesh - and Erasmus sees a clear parallel between ancient philosophers and the Apostle here:

${ }^{11}$ Erasmus (as in n. 1), Enchiridion, p. 54; The Enchiridion, pp. 81-82.

${ }^{12}$ Erasmus (as in n. 1), Enchiridion, p. 54. Note, moreover, that the distinction between three types of immoral, neutral and ethically sound behaviour which occur in the example of the judge, reflects the anthropological view of man that Erasmus took over from Origen. Cf. J. D. Tracy, Erasmus: The Growth of a Mind (Geneva, 1972), pp. 8687: "From Origen [Erasmus] adopted the tripartite division of human nature into flesh (corrupt), soul (neutral) and spirit (free from the taint of sin)". 
let the philosophers carry little weight, except for the fact all these things [i.e., the battles that result from knowing the difference between "reason" and "passion"] are taught in the Holy Scriptures, though not in the same terms. What the philosophers call reason Paul sometimes refers to as spirit, sometimes as the inner man, sometimes as the law of the mind. What they call passions he now calls the flesh, now the body, now the outward man, now the law of bodily members. ${ }^{13}$

Erasmus' position in moral philosophy was all about body and mind. With classical views on the bodily passions surfacing right at the heart of a book devoted to spiritual salvation and redemption, a complete harmony of philosophical and religious aims was suggested, as well as a complete identity of the means of attaining them. Nor is the philosophical interpretation of the Pauline theme limited to Platonism. In the Enchiridion, a hermeneutics of Biblical passages concerning the inner and the outer man is immediately preceded by an examination of the "Variety of Passions" such as they occur in the psychological models of Stoics and Peripatetics. ${ }^{14}$ Again, the obvious link between the Pauline motif and the ontological distinction of body and soul is linked to the subject of reason and the passions, resulting in a rather blunt opposition of reason and virtue on the one hand and passion and sin on the other.

Reading the Enchiridion from the standpoint of an outsider, one would even be inclined to think that Christianity is essentially a life-long battle against the urges of the body. Inspired by the idea of the three parts of man, Erasmus evokes the dangers linked to bodily love. Reason, itself identified as the "immortal soul", is situated in "the loftiest part of the body [and] the one closest to heaven", while "the sensual appetite, which lusts for the pleasure of food and drink and which drives us into erotic love" has its place in lower regions, far from "that divine counselor presiding in the lofty citadel". ${ }^{15}$ Small wonder then, that the nature of the "untamed and intractable beast" in the lower regions is demonstrated by the pudenda, more in particular by the part that "continually promotes rebellion in spite of the king's fruitless protests". ${ }^{16}$ At times, Erasmus could out-do even Augustine as a champion of chastity.

${ }^{13}$ Erasmus (as in n. 1), Enchiridion, p. 47; The Enchiridion, p. 72.

${ }^{14}$ Erasmus (as in n. 1), Enchiridion, chapters 6 and 7, respectively entitled "Concerning the Variety of Passions" and "Concerning the Inner and Outer Man and the Two Aspects of Man according to Holy Scripture"; The Enchiridion, pp. 67 and 72.

${ }^{15}$ Erasmus (as in n. 1), Enchiridion, pp. 43-44; The Enchiridion, pp. 66-67.

${ }^{16}$ Erasmus (as in n. 1), Enchiridion, pp. 43-44; The Enchiridion, p. 67. Though we may read into these words an emerging awareness of Erasmus' later notion that sexual activity is an obvious example of human folly, it does not explain Erasmus' very different tone of voice in the Moriae Encomium. Indeed, the latter book has understandably been regarded as giving expression to an "Epicurean" position that is wholly lacking in the Enchiridion. As I have argued elsewhere, however, Erasmus' so-called "Epicureanism" in the Praise of Folly is linked to a specific organisation of arguments, rather than to a specific position in moral philosophy. See my forthcoming article "Quid aliud est, quam insanire? Erasmus, Valla and the Stoic-Epicurean Controversy", to be published in the proceedings of the Conference Erasmo e la Cultura Europea that was held in Turin, Italy, on 7-8 September 2006. 
If, however, we may conclude that Erasmus' position in moral philosophy was all about body and mind, this does not mean that the question of mindversus-body was restricted to questions of sexuality. Far more important to the history of ethics is the fact that the question of body and mind was also linked to a specific set of ideas about the pleasurable gains to be won by choosing the road to virtue. In this, religion and philosophy could once more be combined, since the philosophical idea of a mental bonus on right choices in life mirrored the religious idea of beatification. Temperance with respect to primary human desires might release a type of mental energy far more positive, more steady and enduring. Had not all ancient philosophical schools, despite their apparent differences, affirmed this?

\section{SWEET PIETY AND MORAL TRANSFORMATION}

What fruits awaited the virtuous? In Erasmus' Epicureus colloquy, the character Hedonius personified both the Epicurean and the religious points of view in a battle between Stoicism and Epicureanism, the two giants of Hellenistic morality. Arguing that "there are no people more Epicurean than godly Christians", Hedonius' Epicureanism, however, is of an uncommon type. ${ }^{17}$ On the basis of a dualism starker than that of Descartes, Erasmus has Hedonius and his Stoic interlocutor Spudaeus establish that, for humans at least, the power of the mind is the one and only fountain of pleasure. To prove this, Erasmus offers a questionable series of argumentative steps, focusing on the notion of conscience. Hedonius argues that nothing is happier than a good conscience since, as Plautus had said, "nothing is more wretched" than a bad one. ${ }^{18} \mathrm{Next}$, the idea is introduced that there are pleasures that exceed and are more powerful than bodily pleasures. Having determined the peculiarity of mental delights in man and the inadequacy of purely bodily comforts for human needs, Erasmus goes on to conclude that it is in mental pleasures alone that a force resides which may overcome all pains and "render pleasant what is in itself bitter". ${ }^{19}$

Presenting the power of mind over matter as the only source of pleasure, Erasmus' Epicureanism is at variance with a key element of ancient Epicurean thought, namely the idea that the ultimate end of all human endeavour may be subsumed under a single concept of "pleasure". More important, however, than

${ }^{17}$ Desiderius Erasmus, Epicureus, in Opera omnia Desiderii Erasmi Roterodami, series I, vol. 3, ed. L.-E. Halkin, F. Bierlaire and R. Hoven (Amsterdam, 1972), p. 721. Quotation from Collected Works of Erasmus, vol. 40: The Colloquies, ed. C. R. Thompson (Toronto, 1997), p. 1075; The Colloquies of Erasmus, ed. C. R. Thompson (Chicago, 1965), p. 538.

${ }^{18}$ Erasmus (as in n. 17), Epicureus, p. 721; Collected Works, pp. 1075-1076; The Colloquies, p. 539. Cf. Plautus, Mostellaria 3.1.544: "Nihil est miserius quam animus hominis conscius".

${ }^{19}$ Erasmus (as in n. 17), Epicureus, pp. 723-772 quotation from p. 723; Collected Works, pp. 1077-1079; quotation from p. 1077; The Colloquies, pp. 540-542; quotation from p. 540. 
his inauspicious interpretation of Epicureanism, is the fact that Erasmus uses the Epicurean notion of hêdonê to highlight the contrast between what he regards as common and "unlawful" pleasures and their alternative, the pleasure he elsewhere calls "another kind" of pleasure - the pleasure "which will last, pure and unchanging, all through a man's life". ${ }^{20}$ The idea that non-mental pleasures have no lasting effect is illustrated by the venereal diseases that "young men get from whoring". ${ }^{21}$ And even if there will be no such negative effects, our mental make-up will ensure that every illicit indulgence has a bad taste to it. Erasmus tells us that a guilty conscience is "always the companion of unlawful pleasure" and adds the grim foresight of man's despair in old age when the threatening prospect of death will become ever more urgent. ${ }^{22}$

Again, however, the severe restriction on the enjoyment of alternative pleasures is subordinate to the positive message that there is a higher kind of pleasure to be found within the spiritual realm. Although Erasmus addresses philosophical arguments and borrows Epicurean notions to highlight this view, his defence of Epicureanism does not make him an Epicurean in philosophy. Rather, it is exemplary for the way in which the Philosophia Christi tied together religious and philosophical viewpoints. Indeed, Erasmus' philosophical outlook was never restricted to any philosophical school. Though he would always remain faithful to the Platonic maxim of distinguishing what is mental from what is physical, a further allegiance to Plato or other philosophers was a matter of lesser concern. Where Christ speaks to Erasmus, Plato is never far off, but Plato's spokesman could just as well be a Stoic, an Epicurean, or even an Aristotelian. In the Epicureus colloquy, the Stoic Spudaeus illustrates the strong power of mind over matter with the example of lovers defying the winter cold when they hold their vigils outside the beloved's house. Hedonius' reply to this is that the spirit of Christ is even more effective. ${ }^{23}$ None of the pagan philosophical doctrines, in other words, could achieve what the New Testament might accomplish. Nevertheless, philosophical and religious types of spiritual transformation coincided, and the effects of both were essentially the same.

Erasmus repeatedly presented earthly higher pleasures as temporary forms of heavenly beatitude, borrowing an accepted idea of medieval philosophy and one which he had earlier copied from St. Bernard of Clairvaux. ${ }^{24}$ Yet what hap-

${ }^{20}$ Erasmus (as in n. 4), Institutio principis Christiani, p. 144; The Education of a Christian Prince, p. 14.

${ }^{21}$ Erasmus (as in n. 17), Epicureus, p. 727; Collected Works, p. 1080; The Colloquies, p. 543.

${ }^{22}$ Erasmus (as in n. 17), Epicureus, p. 727; Collected Works, p. 1081; The Colloquies, p. 544.

${ }^{23}$ Erasmus (as in n. 17), Epicureus, p. 723; Collected Works, p. 1077; The Colloquies, pp. 540-541.

${ }^{24}$ In De contemptu mundi, Erasmus borrowed form St. Bernard of Clairvaux the idea that he brief, but extreme delights a Christian believer may experience in this life are a prelude to the heavenly delights of the life to come. Cf. Erasmus, De contemptv mvndi, in Opera omnia Desiderii Erasmi Roterodami, series V, vol. 1, ed. S. Dresden (Amsterdam and Oxford, 1977), p. 76. 
pens in Erasmus, is that such earthly spiritual bliss is no longer confined to the mental state of the secluded divine. On the contrary, Erasmus had found a more universal target for spiritual transformation. Denying his fellow ecclesiastics a moral standing beyond that of other Christians, he sought to bestow on every Christian the moral ideals that he had earlier associated with the monastic life. Likewise, both in the Praise of Folly and the Epicureus colloquy, society as a whole is reminded of the "true" Epicurean pleasures that beatifying morality and Christian piety might produce.

At the same time, Erasmus regarded such a spiritual redirection of mental energy as an uncommon phenomenon. Though the Praise of Folly has been characterised as a turning point in Erasmus' oeuvre in that it marks a change from Stoic pessimism towards a more appreciative Epicurean regard of the Christian masses, ${ }^{25}$ Erasmus in fact invariably held on to an element of moral elitism not only in the Folly itself, where he claimed (or rather complained) that "the number of really earnest devotees is so small compared with the grand total of the human race", ${ }^{26}$ but also in the Epicureus colloquy, where he bluntly restates the idea that "what the common crowd hunt by fair means or foul are not true goods". ${ }^{27}$ This, again, is a rather paradoxical opinion from the standpoint of Epicurean philosophy - but then, Erasmus did not seek to establish an Epicurean school within Christian thought. Rather, he saw a fundamental congruity between reason and faith in the way both philosophy and religion emphasised the need for breaking with a mental servitude to "bodily" desires in such a way that far worthier types of mental energy would be set free than those ordinarily craved for - especially those craved for by the vulgus.

Such a combination of moral optimism with mental elitism was a way of thinking as loosely linked to any of the philosophical schools as it was ubiquitously accepted in early-modern moral philosophical systems. As Erasmus' one-time pupil Juan Luis Vives stated in his widespread Introduction to Wisdom (1524) that functioned as a Christian Epictetus as much as a schoolboy's manual:

Pleasure - a pure, total and continual delectation - arises only in those things which appertain to the mind. ${ }^{28}$

${ }^{25}$ Tracy, Erasmus: The Growth of a Mind (as in n. 12), p. 124.

${ }^{26} \mathrm{Cf}$. Erasmus, Moriae encomivm id est Stvltitiae lavs, in Opera omnia Desiderii Erasmi Roterodami, series IV, vol. 3, ed. C. H. Miller (Amsterdam and Oxford, 1979), p. 190; translation from Erasmus, The Praise of Folly and Other Writings, ed. R. M. Adams (New York and London, 1989), p. 83.

${ }^{27}$ Erasmus (as in n. 17), Epicureus, p. 724; quotation from Collected Works, p. 1078; The Colloquies, p. 542.

${ }^{28}$ Juan Luis Vives, Ad sapientiam introductio, § 31. Quoted from Vives' Introduction to Wisdom: A Renaissance Textbook, ed. M. L. Torbiner (New York, 1968), p. 88. 


\section{PHILOSOPHICO-RELIGIOUS OPTIMISM}

Higher pleasures had of course always played a role in moral philosophy. The Stoic gaudium that was the inherent result of the virtuous way, though not a reward to be aspired for its own sake, was nevertheless a bonus awaiting the wise. Platonic forms of assimilation to the divine and Aristotelian ideas on the pre-eminence of contemplation equally alluded to the idea that there was a mental advantage to such higher psychological states. On account of its identification of pagan philosophical ends with Christian religious aims, however, Erasmus' emphasis on the need and attainability of a moral transformation was more typical for the early-modern period. If humanist authors had always adopted a pedagogical stance toward the moral development of human individuals, those that exhibited philosophical beyond purely pedagogical interests could easily be inclined to identify piety with mental liberation, ignorance with sin, the vulgus with the damnable, the elect with the wise, and philosophical schooling with religious initiation. Likewise, in Giovanni Pico's manifesto of Renaissance moral thought, De dignitate hominis, exhortations to climb the stairs of philosophical development are accompanied by the idea that beatifying consequences may result. In becoming divine, one is promised the effects of sharing in divinity. Moral development, according to Pico, was a question of sensing and savouring the path to virtue to the point of becoming intoxicated and excited. "Who does not", Pico argues,

set all human things at a lower value and, contemning the goods of fortune and neglecting the body, does not desire, while still continuing on earth, to become the drinking-companion of the gods; and, drunken in the nectar of eternity, to bestow the gift of immortality upon the mortal animal?

Pico also mentions the form of rapture that Plato saw as the privilege of the wise and as a higher form of madness:

Who does not wish to have breathed into him the Socratic frenzies sung by Plato in the Phaedrus $[\ldots] ?^{29}$

Alluding to Jacob's ladder, one of Pico's favourite metaphors, as well as to the message of I Timothy 6:16, Erasmus explicitly linked the experience of beatitude to the idea of a divine repayment:

${ }^{29}$ Giovanni Pico della Mirandola, De hominis dignitate, in Giovanni Pico della Mirandola and Gian Francesco Pico, Opera omnia (Basel: Heinricus Petrus, 1557); repr. Opera omnia, ed. C. Vasoli (Hildesheim, 1996; 2005²), p. 319; G. Pico della Mirandola, De hominis dignitate, Heptaplus, De ente et uno e Scritti vari, ed. E. Garin (Florence, 1942), p. 122. Translation from Pico della Mirandola, On the Dignity of Man, ed. G. Wallis, P. J. W. Miller and D. Carmichael (Indianapolis, 1965), p. 13. 
if you will try with all your might to rise out of the darkness and CONFUSION of your sensory experience, He will graciously come to meet you from His inaccessible Light and inscrutable Stillness [...].

God's reward is found in the "prizes He gives for the efforts of those who contend for them". 30

Whether it was Plato's ecstasy, the quasi-Epicurean idea of a higher pleasure, or simply the concept that virtue was its own reward, all such notions could equally serve as an expression for the idea that there was a divine dividend on moral growth. Erasmus described it in terms of the "rich harvest of all virtue": an "inward and secret joy known only by those who have achieved it, a joy which does not vanish and melt away with the delights of this world, but expands and swells into bliss everlasting". "Much like the paradigmatic Philosophia Christi itself, later articulations of the ancient ideas of a virtue-inspired gaudium, laetitia intellectualis, or beatitudo, suggest a similar fusion of religious and philosophical beliefs.

Close to Erasmus' own position is the "spiritualist" stance we find, for instance, in the work of Dirck Volckertsz. Coornhert (1522-1590), the man who published what is generally held to be the first modern Ethics in a vernacular language, his Zedekunst of 1584. With an aim of advancing the moral upbringing of his contemporaries, Coornhert was ready to incorporate the lessons of all philosophical schools into the many pamphlets that he wrote. Even in his denunciation of Justus Lipsius' Politicorum sive civilis doctrina libri sex (1589), Coornhert appeals to the "manly constancy and Godly wisdom" (manlyke standvastigheydt ende Godlyke wijsheydt) of the Leiden burgomasters and city councils - the same classical ideals, in other words, that had been the focus of Lipsius' own philosophical interest. In a pamphlet, moreover, that summarises Coornhert's view of moral perfectibility under the heading On the Origin of Sin: Plato's Testimony, Stoic and Epicurean influences are just as apparent as Erasmian and Platonic themes. ${ }^{32}$ His dialogue In Pursuit of the Highest Good (Opperste ghoeds Nasporinghe, 1590) is again exemplary for this type of eclecticism in its way of adding one moral target on the other: tranquillity (rust), pleasure (lust, wellust), virtue (deugd) and love (liefde). Though the treatise includes subtle arguments for and against the various interpretations of the summum bonum, it ultimately does not reject any one of them in particular, but

${ }^{30}$ Erasmus (as in n. 1), Enchiridion, pp. 88 and 25; The Enchiridion, pp. 130 and 42, respectively. Note that, although Erasmus never shared in the metaphysical or cosmological views of Ficinian Platonism, he nevertheless, as M. A. Screech explains, "presents the bare bones of this doctrine [i.e., of Platonic mania] with considerable sympathy". The potential of this notion, for Erasmus, lay neither in metaphysics or cosmology, nor even in epistemology, but entirely in its moral application. Cf. M. A. Screech, Ecstasy and the Praise of Folly (London, 1980), p. 140.

${ }_{31}$ Erasmus (as in n. 1), Enchiridion, p. 40; The Enchiridion, p. 62.

${ }^{32}$ Dirck Volckertsz. Coornhert, Vande oorsaecke vande Zonde,'tghetuygh Platonis, (c. 1560-1561), in Dieryck Volckertsz. Coornherts Wercken, ed. C. A. Boomgaert, vol. 1 (Amsterdam, 1630), fol. 134r-v. 
rather accepts them all as different aspects that may contribute in one way or another to a universal notion of moral growth. ${ }^{33}$

Coornhert presented a "secularised" form of moral thought in the sense that he combined a positive belief in spiritual reformation with a consciousness of its practical value. Reiterating the traditional Platonic idea we find in Erasmus, Pico and many others, that what is "beastly" in man should be replaced by what is "godlike", Coornhert adds that what is called "godlike" in moral philosophy is to be interpreted in social terms. In a community of men, becoming godlike is to attain a certain level of moral maturity. The difference between the adult and the child - another moral fil rouge of Pauline and Augustinian origin - thus becomes very prominent in Coornhert, and brings to light the fundamentally pedagogical core of his moral philosophy. Cornelis Boomgaert, one of Coornhert's interlocutors in Opperste ghoeds Nasporinghe, offers the image of the young apple tree that lives only for itself and does not, as yet, bear any fruit. Likewise, the child does not yet know its goal in life; it is still unaware of its higher potentials and has necessarily to make use of its primary lusts and desires in order to survive. An adult, on the other hand, should know better. ${ }^{34}$ "[Through] no fault of our own", Coornhert argues, "are we all born unwise, yet no one will stay unwise if not through his own fault". ${ }^{35}$ Man becomes "godlike, that is godly", says Coornhert, "when he no longer lives for himself, but for others, and is most useful to most other people in respect of what is best". ${ }^{36}$ Coornhert offers a precise standard for the age at which this godlikeness can be tested, and maturity be demanded of one's fellow men. It is at or around the age of twenty:

Behold, then, how God justly demands to be loved by all adult people as the highest good, in that they have received from Him the possibility within themselves to do so; and that it is therefore a shortcoming when a human being that has come to the use of his reason - above his twentieth year, that is - loves himself, although he is a much more evil thing than God, more than [he loves] God [...]. ${ }^{37}$

The mature person is distinguished from the child by an ability to want for him or herself nothing but the divine nature that he or she may take part in, acquir-

${ }^{33}$ Cf. Dirck Volckertsz. Coornhert, Opperste ghoeds Nasporinghe (Gouda, 1590). A modern edition may be found in Dirck Volckertsz. Coornhert, Op zoek naar het hoogste goed, ed. H. Bonger, Geschiedenis van de wijsbegeerte in Nederland, vol. 7 (Baarn, 1987), pp. 47-113.

${ }^{34}$ Cf. Coornhert, Op zoek naar het hoogste goed (as in n. 33), pp. 83, 101.

${ }^{35}$ Dirck Volckertsz. Coornhert, Onverstandigh blijven is des Menschen eenighe zonde, oorsake van alle Dolinghe, in Dieryck Volckertsz. Coornherts Wercken, ed. C. A. Boomgaert, vol. 1 (Amsterdam: Jacob Aertsz. Colom, 1630), fol. 130r. Cf. H. Bonger, "Inleiding", in Coornhert, Op zoek naar het hoogste goed (as in n. 33), p. 26. Translation HvR.

${ }^{36}$ Cf. Coornhert, Op zoek naar het hoogste goed (as in n. 33), pp. 101-102.

${ }^{37}$ Coornhert, Opperste ghoeds Nasporinghe (as in n. 33), p. 107. Cf. Coornhert, $O p$ zoek naar het hoogste goed (as in n. 33), p. 108. 
ing the mental disposition of being "full of goodness, to the point of brimming over". 38

In Coornhert, the promise of a spiritual dividend on moral transformation is also dealt with very explicitly. Testing the various candidates for the position of the summum bonum in Opperste ghoeds Nasporinghe, Coornhert puts forward the question

who would desire virtue, let alone with difficulty seek to acquire it and even excercise it with an effort, if it did not arouse a feeling of pleasure? $?^{39}$

The statement that virtue is not praised for itself, but rather on account of the pleasure that it kindles, is the classic position of the Epicurean in other examples of such debates. In Coornhert, however, the idea that there is a reward to virtue occurs in a more complicated fashion. In an imaginary dialogue with his Dutch friend Hendrick Laurensz Spieghel, Coornhert himself takes up the defence of pleasure. The concept of pleasure is criticised, however, and Opperste ghoeds Nasporinghe ultimately focuses on virtue and unselfish love of God rather than on lust. Yet the notion of pleasure is not given up at any point.

Keeping the notion of pleasure aboard, albeit in a purely moralised and "mentalised" form, is characteristic of the broader, early-modern, concern for philosophical felicity - a concern that no longer accepted the typical EpicureanStoic antithesis as it was found in Cicero or Valla. Though the defence of pleasure in Opperste ghoeds Nasporinghe forms part of a presentation of the Epicurean position on ends, the self-conscious deployment of the pleasureargument no longer functions as an argument against the Stoic view. If one accepts both an Erasmian emphasis on "higher" pleasures and the notion of a virtue that is its own reward, the concept of pleasure is easily reinterpreted as a spiritual reward for a morally acceptable attitude. Going beyond Erasmus himself, moreover, Coornhert consciously merged the Epicurean and Stoic positions. It is not the case, he argues, that there are now two types of summum bonum, "but wisdom, temperance, fortitude (sterkte) and justice are linked to pleasure in such a way that one cannot distinguish between them. Who has the one, must have the other". ${ }^{40}$

Though Coornhert's interlocutor in this part of the dialogue, Henrick Laurensz Spieghel, forces Coornhert to admit that not all pleasures are of a virtuous kind, the case for pleasure has nevertheless been made and its connection to virtue is never retracted. The idea, then, is that all morality is pleasure-driven, and instead of a choice for or against a specific school of thought, the focus of moral instruction is on the idea that nurtured mental dispositions have to be valued higher than natural ones, even if this is simply "for the pleasure that they produce". As in Erasmus, such a position comes not only with a re-evaluation

\footnotetext{
${ }^{38}$ Coornhert, Op zoek naar het hoogste goed (as in n. 33), p. 112.

${ }^{39}$ Coornhert, Op zoek naar het hoogste goed (as in n. 33), p. 82. Cf. also p. 88:

"Maar die [deugd] wordt niet om haarzelf geprezen, maar om de wellust die zij baart".

${ }^{40}$ Coornhert, Op zoek naar het hoogste goed (as in n. 33), p. 89.

${ }^{41}$ Coornhert, Op zoek naar het hoogste goed (as in n. 33), p. 88.
} 
of classical philosophical views, but also with a reinterpretation of the concept of pleasure as such. Moral pleasure, a pleasure of a purely spiritual nature, is an earthly form of beatitude styled in the religious phraseology through which it is linked to St. Paul's notion of heavenly delights. It is a mental bonus sharply to be distinguished from lower enjoyments, to be identified with the religious type of inspiration that, as far as Coornhert is concerned, is the direct effect of a right understanding and knowledge of God. ${ }^{42}$

\section{ORTHODOX OPTIMISTS}

The idea that the aims and the effects of religion and philosophy coincided, is even found in books of a purely religious nature. Petrus Geesteranus' (ca. 16201673) De constantia Christiana of 1679, though it is not the Protestant reaction to Justus Lipsius' De constantia that it has been thought to be, ${ }^{43}$ was in any case not intended as a defence of the Stoic position. Offering a biblical account of constancy instead, it traces the virtues of fortitude, temperance and perseverance as they are found in the Bible, whilst adding philosophical authorities (including Lipsius himself) to the authority of Holy Writ. True to his Christian position, Geesteranus insists that beatitude may only be found beyond this life indeed, only after the resurrection of the body; a necessary specification of which even Erasmus had been aware. ${ }^{44}$

However, although a permanent gaudium is not to be found on earth, Geesteranus still explains his religious position in the Stoic terminology that he may have found in Lipsius. The latter had presented his own account of philosophico-religious mental training in the dark and pessimistic colours of bearing up heroically with life's austerities and God's punishments, rather than in the cheerful terms of pious joys. Here, too, however, the apparatus for overcoming hardships was to be found in our mental capacity to do so. The human

${ }^{42}$ As Coornhert explains in a passage that tries to salvage a certain notion of grace, the love of God is the direct effect of a true knowledge of God. Cf. Coornhert, Op zoek naar het hoogste goed (as in n. 33), p. 108: "Zo is ook de ware godskennis met de liefde tot God (haar gevolg) niet minder Gods eigendom in de ijverige mens dan de redelijkheid of de mogelijkheid tot de ware godskennis zelf". And ibidem: "Geef dan ook toe dat God met alle recht eist van de volwassen mens de vruchtbare woeker naar ieders vermogen tot de kennis en de liefde tot God, hoewel zij die niet zelf maar wel de mogelijkheid daartoe van God hebben".

${ }^{43}$ Lipsius's Dutch editor Piet Schrijvers characterised Geesteranus' posthumously published work (1679) as a Protestant reply to De constantia. Cf. Schrijvers, "Inleiding", in Justus Lipsius, Over standvastigheid bij algemene rampspoed, ed. P. H. Schrijvers (Baarn, 1983), pp. 18-19. On Geesteranus, see also my article in The Dictionary of Seventeenth and Eighteenth-Century Dutch Philosophers (Bristol, 2003), vol. 1, pp. 321322.

${ }^{44}$ Erasmus, Moriae Encomivm (as in n. 26), p. 192: "Iam haec felicitas, quanquam tum demum perfecta contigit cum animi receptis pristinis corporibus immoralitate donabuntur $[\ldots] "$. 
mind is always in a situation of war, or at least "armed peace" with its dualistic counterpart, the body. Turned to God as a sunflower is turned to the Sun, it is reason, as the divine and heavenly part of the soul that, according to Lipsius, may set us free, may ease our pain, and make us "calm amidst wild billows". 45 Again, the aim of mental training is the positive bonus that awaits the wise - in Lipsius' case, tranquillity.

Though he rejected the notion of a permanent beatitude on earth, Geesteranus nevertheless interpreted our future bliss in similar philosophical terms. What one may experience in heaven will be a permanent type of "tranquillity", an absentia malorum and a bonorum possessio that "continually promotes and brings about a gaudium infinitum" - a Christian view the author unproblematically substantiates by adding a reference to Seneca's description of mental peace and tranquillity beyond death. ${ }^{46}$

The idea that real beatitude is to be obtained only in heaven was a widespread idea, especially in the works of those theologians and philosophers who defended more orthodox religious positions. The Leiden theologian Antonius Walaeus (1573-1639), for instance, though forming part of the Aristotelian commentary tradition on account of his Compendium ethicae Aristotelicae ad normam veritatis Christianae revocatum (1620), rebutted Aristotle for not having seen, as Plato had, that the aspiration to virtue which is demanded in this life "is merely the path or means to eternal happiness in the future". Meanwhile, the idea that the combination of contemplative and active virtues leads to a perfect happiness in this life is not thereby rejected. Indeed, Walaeus accepted the Aristotelian virtues as "good works" which "are the means by which we should strive towards our future happiness". ${ }^{47}$ This would seem to imply that earthly means to salvation are also efficacious in producing earthly forms of beatitude. Having praised Plato, who had argued that, to a certain degree, the highest good can be achieved in this life, although, according to the Christian truth, its perfection will only come in the next, Walaeus attempted to exonerate Aristotle as well, arguing that Aristotle, too, "where, in Ethics, book 10, contemplative beatitude is discussed", seems to have accepted the idea that the highest good comes in two different forms. ${ }^{48}$

Walaeus' case is also a significant example of early modern philosophical neutrality where it comes to evaluating ancient moral systems. In fact, with the exception of the Epicurean philosophy, which equates the summum bonum with

${ }^{45}$ Justus Lipsius, De constantia libri duo, qui alloquium praecipuè continent in publicis malis (Antwerp, 1584), Book 1, chapters 5 and 6, pp. 14, 17.

${ }^{46}$ Petrus Geesteranus, De constantia Christiana tam in secundis quam in adversis tractatus aequè utilis ac eximius, ed. P. van Loon and T. Graswinckel (Leiden: Daniel van Gaesbeeck, 1679), pp. 67 and 55-56, respectively. Cf. Seneca, De consolatione ad Marciam, 19.6-20.2.

${ }^{47}$ Antonius Walaeus, Compendium ethicae Aristotelicae ad normam veritatis Christianae revocatum (Leiden: Elsevier, 1620), pp. 19 and 50, respectively. Translation by J. Monfasani from Cambridge Translations of Renaissance Philosophical Texts. Vol. 1: Moral Philosophy, ed. J. Kraye (Cambridge, 1997), p. 124.

${ }^{48}$ Walaeus, Compendium (as in n. 47), p. 19. 
pleasure, all others, though defining the highest good in a variety of ways as "a disposition to virtue" (Stoics), "the activity of virtue" (Peripatetics), or "the union of man with God" (Platonists), all come down to the same thing, namely that man's highest good is to be found in virtue, "the most agreeable, most honourable and utmost praiseworthy" of human potentials. Walaeus even shows a further allegiance to the broad current of early modern moral optimism, where he acknowledges that even Epicureanism may be included in this list, if it is interpreted in the way "modern" authors have interpreted it. These recentiores have vindicated the ancient Epicurean position by defining as "pleasure"

not that kind of pleasure that humans have in common with animals, but the kind of pleasure of the mind that is pure and withdrawn from bodily things, which arises in the human mind from the knowledge of eminent things and the activity of honourable deeds. ${ }^{49}$

It would, Walaeus accordingly argues, "not be all too mistaken" to consider pleasure as the highest good if one interprets the Epicurean position in this modern way. ${ }^{50}$ Virtue and pleasure, indeed, stand very close, so that the question should be answered whether it is the virtuous or the pleasurable aspects that form the essence of the summum bonum. Doing so, Walaeus grouped together all the various concepts early-modern philosophy accepted as expressions of the idea of a spiritual bonus on moral growth: animi tranquillitas, laetitia, gaudium, voluptas animi, felicitas, beatitudo - things not only philosophers, but also Holy Writ itself had promised to mankind as the praemium and finis of "our labours". 51

In the end, Walaeus opts for the idea that, strictly speaking, mental tranquillity in itself does not make up the essence of the highest good. Nevertheless, it is intricately and inseparably linked to virtue as its "inseparable effect and unique correlative (adiunctum proprium)". 52 This discredits the view that virtue would simply be the cause of the highest good, and pleasure its essence, or form. At the same time, Walaeus' discussion of the summum bonum, and his acceptance of the idea that pleasurable aspects form an essential part of it, illustrates to what extent neo-scholastic discussions, too, had accepted the idea that all ancient philosophical schools had only offered different definitions of what was basically a single position. Where his object had been to explain Aristotle's Ethica Nicomachea in Christian terms, Walaeus in fact presented a treatise of ethics in which all pagan systems were seen as so many partial attempts to identify what man could achieve in terms of mental felicity. Even if postReformation and post-Tridentine theology kept philosophers from too easily

\footnotetext{
${ }^{49}$ Walaeus, Compendium (as in n. 47), p. 23.

${ }^{50}$ Walaeus, Compendium (as in n. 47), p. 24: "non esset vsque adeo absurda".

${ }^{51}$ Walaeus, Compendium (as in n. 47), pp. 41-42. For Biblical refrences, see, for instance, the use of finis in Proverbs 22:4 and the New Testament use of the term merces (rather than praemium) for the Greek misthós.

${ }^{52}$ Walaeus, Compendium (as in n. 47), p. 43.
} 
equating the gift of grace with earthly beatitude - something of which Lipsius himself seems initially to have been remarkably unworried ${ }^{53}-$ the essential $^{2}$ identification of moral and theological bliss could nevertheless be maintained and explained within accepted philosophical and theological boundaries.

\section{POST-CARTESIAN PARTISANS}

Even when natural philosophy dramatically changed, philosophers still continued - at least for a generation or two - to search for the highest good, and to describe the state of bliss it was thought to produce in terms that linked philosophy to religion. Lipsius' image of the tranquil mind standing up to the wild waves of outer conditions would remain popular even with seventeenth-century Cartesians who explicitly distanced themselves from Stoicism. Thus, Lipsius' Cartesian successor, the Flemish metaphysician and moralist Arnold Geulincx (1624-1669), expressed a quasi-Stoic awareness of the need not to let oneself be enslaved by the pressure of outer conditions, knowing full well that

there is this boundless ocean of miseries, on which I presently toss. I am hurled from one calamity to another, only to sink back as often as not from the latter to the former. $^{54}$

Similarly, at the end of the third book of his Ethics, Spinoza argued it should by now be clear to the reader from what had been said

that we are driven about in many ways by external causes, and that, like waves on the sea, driven by contrary winds, we toss about, not knowing our outcome and fate. ${ }^{55}$

${ }^{53}$ In his own copy of De constantia, Lipsius was soon to scribble "and God" in the margin wherever right reason was discussed. Cf. Schrijvers, "Inleiding", p. 15. In line with this, the dedicatory letter to the second edition of De constantia, instead of simply mentioning "wisdom" as the true means of attaining "tranquillity" and "calm", was to mention "wisdom [...] together with Holy Writ". Cf. the original version of Lipsius' De constantia (as in n. 45), sig. *2v: "quoniam, nisi fallor, interclusam diu \& spinis obsitam hanc Sapientiæ viam, sternere \& munire aggredimur primi. quæ illa profectò est, quæ sola possit ducere ad Tranquillitatem \& Quietem". In the 1585 edition a separate preface to the reader was added discussing the relationship between theology and philosophy. The text of the original dedication was changed to: "quæ illa profectò est, quæ cum diuinis litteris coniuncta, poßit ducere ad Tranquillitatem \& Quietem". Justus Lipsius, De constantia libri duo, qui alloquium praecipuè continent in publicis malis (Antwerp, 1585), sig. *4v.

${ }^{54}$ A. Geulincx, Opera philosophica, ed. J. P. N. Land (The Hague, 1891-1893); Sämtliche Schriften, ed. H. J. de Vleeschauwer (Stuttgart, 1965-1968), vol. 3, p. 55. Translation from A. Geulincx, Ethics: With Samuel Beckett's Notes, transl. M. Wilson, ed. H. van Ruler, A. Uhlmann, M. Wilson (Leiden, 2006), p. 54.

${ }^{55}$ Spinoza, Ethica III, Propositio 59, Scholium, in Opera (as in n. 2), vol. 2, p. 189. Translation from A Spinoza Reader (as in n. 2), p. 187. 
Many more examples could be given of such classical ways of expression having become the standard jargon of seventeenth-century theories of ethics. However, the image of human life as a turbulent sea was, again, far more than an example of the remaining force of philological training. In philosophical terms, it expressed a shared conviction that solace in life was to be found in reason alone.

Likewise, seventeenth-century thinkers continued to emphasise the shared outlook of philosophy and religion. Both aimed at acquiring that uncanny form of happiness that only the virtuous were likely to taste. Geulincx' pupil Cornelis Bontekoe (c. 1644-1685) considered a "sweet affection" [soete genegenheit] to all things (and to God in particular) and a "lasting happiness" [gedurige vreugde] to be the ultimate goal of both the "good philosopher" and the "enlightened Christian". ${ }^{56}$ Geulincx himself equally underlined the private and inexplicable character of delights known only to the virtuous:

The chaste delights of a mind dedicated to God, of a mind sworn to God's Law, and completely forswearing itself; chaste delights (what can I say beyond the name of a thing that cannot be expressed by saying it?), dear delights, pure, generous delights. No-one can begin to be acquainted with such joys unless he rejoices in them: these joys are all joys of the heart. ${ }^{57}$

Depicting his new set of four cardinal virtues as Goddesses, "because they join and link us so closely with God", Geulincx accentuated in his Ethics that these virtues are a unique source of beatitude, indeed of "all our blessedness [beatitudo] and happiness [felicitas]". ${ }^{58}$ Again, this is also what Spinoza would claim, arguing that our "salvation [salus], or blessedness [beatitudo], or freedom [libertas]" consists in a "constant and eternal love of God, or in God's love for men". Recognising that there was a fundamental likeness between philosophy and religion on this point, Spinoza added that such spiritual blessedness is identical to what "is called glory [Gloria] in the Sacred Scriptures". 59

Elsewhere, I have pointed to the various psychological principles that accompanied this type of philosophical belief in the possibility of a morally induced form of mental detachment: the notion that happiness is intimately connected to a knowledge of the truth; that wilful abstinence and moderation are uniquely beneficial; that mental freedom may be won on the basis of insight alone; that there is a type of experience which is known only to the initiated and which is not communicable; that such exceptional experiences come in the form of an ecstatic joy; and, finally, that the latter is connected to some type of

${ }^{56}$ Cornelis Bontekoe, Opbouw der Medicyne, Chapter 13, "Van de middelen, om het Leven en de Gesondheid lang te bewaren, sich voor Siektens te hoeden, en d'Ouderdom en Dood een langen tijd af te weren", in Alle de Philosophische, Medicinale en Chymische Werken (Amsterdam: Jan ten Hoorn, 1689), vol. 2, part 3.231.

${ }^{57}$ Geulincx (as in n. 54), Opera philosophica, vol. 3, p. 62; Ethics, p. 61.

${ }^{58}$ Geulincx (as in n. 54), Opera philosophica, vol. 3, p. 193; Ethics, p. 210.

${ }^{59}$ Spinoza, Ethica, V, Proposito 36, Scholium, in Opera (as in n. 2), vol. 2, p. 303. Translations from A Spinoza Reader (as in n. 2), pp. 260-261. 
ego-loss. ${ }^{60}$ All these were common aspects of an attitude that was as pessimistic about the human condition itself as it was optimistic in its belief in the philosophical means and goals that promised salvation. Moral growth was a question of mental training associated with the idea that, as Arnold Geulincx was to repeat in the manner of Coornhert, "we are born infants; and as a result will cleave first to sensations and Passions rather than Reason". 61

Meanwhile, more scholastically inclined authors continued to compare philosophical to theological virtues and to discuss and rank the various philosophical schools accordingly. In his Synopsis ethices (first published in 1675), Descartes' translator, the Remonstrant theologian Étienne de Courcelles (15861659), refused to accept the bifurcation of ethics into a philosophical and a theological branch. Neatly distinguishing mental from corporeal, and praiseworthy from base and indifferent joys, Courcelles took position inbetween the supposed Epicurean acclaims and Platonico-Stoic condemnations of pleasure. He also added a chapter on beatitude in which all the various aspects of the summum bonum were considered. ${ }^{62}$ The accent in this eudaemonology is on the imperfection of beatitude in this life. Nevertheless, De Courcelles argues once again that all philosophers concur in finding beatitude in virtue, and that they disagree "in word rather than in the thing itself". ${ }^{63}$ In addition, he sanctions Epicurus, who, he says, was misread with respect to pleasure and had only sought the kind of indolentia that all agreed was "a companion and supplement to the supreme good".

If De Courcelles showed his theological background by putting the afterlife firmly back on the agenda, he did so for psychologically interesting reasons. It is, he argued, only through the hope for a life beyond that peace and quiet can be found in the present. This argument actually implies that, rather than virtue, it is "mental tranquillity and pleasure" that make up the essence of the summum bonum. One can, De Courcelles argues, be virtuous and "suffer great misfortunes" at the same time. Only virtue accompanied by a religious consolation of hope will ultimately work and have the beatifying effect that may rightfully claim the name of "highest good". ${ }^{64}$ It is thus no surprise that De Courcelles argued that ethics belongs to philosophy and theology alike, at least if one accepts these as being distinct disciplines. If, however,

Philosophy is considered as a collection of all praiseworthy arts, in such a way as not only pleased Cicero and Plato, but also many of the early Christians, who assigned the Christian religion the name of Evangelic Philosophy, there is no doubt but that

${ }^{60}$ Cf. my "Le sage et l'amour de Dieu: Conceptions philosophiques de la béatitude d'Érasme à Spinoza", in Spinoza et la Renaissance, ed. S. Ansaldi (Paris, 2007), pp. 57-80.

${ }^{61}$ Geulincx (as in n. 54), Opera philosophica, vol. 3, p. 106; Ethics, p. 111.

${ }^{62}$ Cf. Stephanus Curcellaeus, Synopsis ethices, in Opera theologica, ed. Philippus van Limborch (Amsterdam: Daniel Elsevier, 1675), pp. 983, 994 and 1016-1018, respectively.

${ }_{63}$ Curcellaeus, Synopsis ethices (as in n. 62), p. 1017. Translation HvR.

${ }^{64}$ Curcellaeus, Synopsis ethices (as in n. 62), pp. 1017-1018. 
Ethics belongs to the province of Philosophy, as even Theology itself belongs to the same. ${ }^{65}$

Thus, the idea of a Philosophia Christi re-enters the stage in a purely philosophical context. Yet if the idea remained widespread that the aims of religion and philosophy coincided, and if entire generations accepted the notion that the path to virtue promised pleasurable effects, ${ }^{66}$ such standpoints had not therefore received universal approval even in early modern times.

\section{POSITIVE DOUBTS}

Dissent was fuelled, and moral philosophy revolutionised, not so much by philosophical considerations, as by a form of pessimism that was crucial to the Christian religion itself. Two main alternatives to the accepted philosophicoreligious stance were based on related, though not identical, considerations: either the attainability of moral happiness with the help of reason was called into doubt, or the concept of a moral happiness as such was flatly rejected. In either case, the alliance of religious and philosophical motivations was regarded deceptive on the grounds that it bred moral illusions.

The first position was in itself more widespread than the radical view it gave rise to. Inspired by the Judeo-Christian notion of man's fallen state, many early-modern thinkers were sceptical of the high-flying ideals of ancient philosophy - the ideal of the Stoic wise man in particular. Even Erasmus, in the Enchiridion, depicted the life of the virtuous Christian soldier in terms of a continued battle against sin. More than a century later, the Christian apologist Petrus Geesteranus, arguing that the subject of temptation (peirasmós, Tentatio) was one of the main subjects in the Bible, ${ }^{67}$ would equally emphasise the need to keep fighting the devil, the world and the flesh. The case of Geulincx proves that similar ideas were found in philosophical treatises. Geulincx puts what he calls "the devil" last in his enumeration of disreputable pleasures, interpreting "the flesh" as something related to "the pleasures of the table and venery", "the world" to "fame" and, lastly, and most conspicuously, "the devil" to the human desire to resist any wilful change of conduct, in other words, to what Geulincx calls "a certain stubbornness or persistence in what one has begun". ${ }^{68}$

Though in Geulincx we thus find a naturalistic, or "philosophical", interpretation of Biblical concepts wholly alien to Geesteranus, he shares the latter's

${ }^{65}$ Curcellaeus, Synopsis ethices (as in n. 62), p. 983.

${ }^{66}$ In my introduction to Arnold Geulincx, Ethics: With Samuel Beckett's Notes (Leiden, 2007), I have tried to indentify some of the social and philosophical factors involved in the disappearance of the concept of beatitude from mainstream philosophy after 1700 .

${ }^{67}$ Geesteranus, De constantia Christiana (as in n. 46), p. 34.

${ }^{68}$ Geulincx (as in n. 54), Opera philosophica, vol. 3, p. 109; Ethics, p. 115. See also his more detailed account of "The Flesh", "The World" and "The Devil" in Treatise 4.68, Opera Philosophica, vol. 3, pp. 113-119; Ethics, pp. 119-126. 
moral pessimism in so far as his analysis, too, satisfies the Christian rule that the battle against vice will never be over, nor sinful proclivities be overcome. In Geulincx, this position is intricately linked to the Augustinian idea - now strengthened by Cartesian physiology - that the passions in themselves are neither good nor bad, but wholly neutral:

Passions are, then, so far as nature is concerned, quite good, though some of them are unpleasant to us or affect us adversely (such as pain, fear, etc.); but so far as morality is concerned they are neither good nor bad for us, but have the same character as seeing and hearing, etc., on account of which no-one is called either virtuous or vicious. $^{69}$

Since it is of the essence of our human condition to have passions, the Stoic notion of apatheia is nonsensical within the Cartesian context. Yet, although these passions themselves are wholly neutral, we have "a great propensity" always to act upon them (which Geulincx calls "a sort of weakness of ours"). ${ }^{70}$ This makes us continually prone to sin - so much so, in fact, that the positive aim of the Stoic wise man eventually to overcome all mental disturbances is ruled out from the start.

Others have claimed that this was the point on which Spinoza diverged from the philosophy of his ancient Stoic examples. As Alexandre Matheron wrote, "in contrast to what the Stoics believed, we cannot make [...] sadness disappear", since it is the effect of exterior causes that shatter our rational desires. ${ }^{71}$ As we have seen, two of his Leiden contemporaries accepted the same thing on Christian grounds. Whether or not Spinoza was right in believing that the Stoic tradition had itself ignored such caveats with respect to the attainability of a lasting mental peace, Geesteranus at least was convinced that the Stoics, and Seneca in particular, had understood very well that in order to find virtue one had to fight a perpetual battle. ${ }^{72}$ Geesteranus himself, of course, held a lasting tranquillity to be beyond our powers, arguing that, in this life at least, peace of mind could be only a short, imperfect and limited affair. ${ }^{73}$ Likewise, Geulincx argued that to search for a lasting peace would lead to a conflict with the cardinal virtue of humility. The whole idea of being virtuous, according to Geulincx, was to accept willingly what one has to endure. The virtuous man is a reasonable man, and will train himself to be always "minded to" what is reasonable:

${ }^{69}$ Geulincx (as in n. 54), Opera philosophica, vol. 3, p. 105; Ethics, p. 110.

${ }^{70}$ Geulincx (as in n. 54), Opera philosophica, vol. 3, p. 105; Ethics, p. 111.

${ }^{71}$ A. Matheron, "Le moment stoïcien de l'Éthique de Spinoza", in Le Stoïcisme aux XVIe et XVIIe siècles, ed. P.-Fr. Moreau and J. Lagrée (Caen, 1994), pp. 159-160. Quotation from p. 159. Translation HvR.

${ }^{72}$ The Bible itself had affirmed this: "Sufficient unto the day is the evil thereof" (Matthew 6:34). Cf. Geesteranus, De constantia Christiana (as in n. 46), p. 54. Geesteranus quotes Seneca's De constantia sapientis, 10.4: "nulla virtus est, quæ non sentias perpeti”. Geesteranus, De constantia Christiana (as in n. 46), pp. 226-227. Cf. L. Annaei Senecae opera qvae svpersvnt, ed. E. Hermes, vol. 1, fasc. 1 (Leipzig, 1905), p. 34: "nulla virtus est, quae non sentiat [sc. sapiens] se perpeti".

${ }^{73}$ Geesteranus, De constantia Christiana (as in n. 46), p. 54. 
Therefore, whatever the virtuous man does, he does willingly, since nothing is at liberty to act on him apart from what Reason dictates is to be done. Whatever he suffers, he suffers willingly, since in Passion, as such (and considered only in itself), there is nothing contrary to Reason, and accordingly neither is there anything to which he is not minded. ${ }^{74}$

Yet despite their pessimism with regard to the possibility of arriving at a lasting happiness, all these authors at least accepted the difficulties concerned as necessary obstacles to be overcome. What Geesteranus, Geulincx and Spinoza shared with Stoicism was that all reasonable efforts at overcoming life and nature's obstacles, even if there would always be moments of despair, were at least always steps in the right direction. A very different and a far more "discordant" type of pessimism is the one that we find in Blaise Pascal.

\section{DISHARMONY}

Pascal's criticism of the supposed similarity between philosophy and religion leads to a direct confrontation between reason and religious inspiration. According to the French philosopher-scientist, the philosophical means that are aimed at the good life are not so much lacking force in comparison to religious means, but actually prevent the individual from attaining the intended end of a lasting beatitude. Beatitude is considered a psychological goal beyond human achievement not for the fact that it aims too high, but because of the mentally damaging consequences of the attempts to attain it.

Though some of Pascal's aphorisms seem hardly to rise above the complaints of contemporary pietistic faultfinders, for instance where he denounces sports and art as idle preoccupations, ${ }^{75}$ the preeminence of his analysis of human vanity lies in its way of presenting as mental delusions the projects that psychologically attract us. Yet, if Pascal is the "anti-humanist" he is reported to be, ${ }^{76}$ his anti-humanism nonetheless involved a very serious interpretation of the aims and aspirations of ancient and early-modern philosophy. More than that, he accepted some of the most basic assumptions of the philosophical tradi-

${ }^{74}$ Geulincx (as in n. 54), Opera philosophica, vol. 3, p. 123; Ethics, p. 130.

${ }^{75}$ Blaise Pascal, Pensées $\S 73$ and 74 according to P. Sellier's edition: Pensées: Nouvelle Édition établie pour la première fois d'après la copie de référence de Gilberte Pascal (Paris, 1976); Blaise Pascal, Pensées: Édition établie d'après la copie de référence de Gilberte Pascal (Paris, 1999). The passages correspond to $\S 39$ and 40 in the edition by Louis Lafuma: Blaise Pascal, Pensées sur la religion et sur quelques autres sujets, in 3 vols. (Paris, 1951); and to $\S \S 141$ and 134 according to Léon Brunschvicg's edition: Opuscules et pensées de Pascal (Paris, 1897); Blaise Pascal, Pensées et opuscules (Paris, $1904^{3}$ ), an edition that may also be found in the last three volumes of the CEuvres de Blaise Pascal, ed. L. Brunschvicg, P. Boutroux and F. Gazier, 14 vols. (Paris, 1904-1914).

${ }^{76}$ Sellier, "Introduction", in Pascal, Pensées (as in n. 75), p. 5: "ce brûlot antihumaniste". 
tion as being all too human, and therefore inescapable, assumptions. Even in criticising such things as human vanity and moral philosophical goals, Pascal was not entirely negative about human intentions as such, nor indeed about the philosophical traditions that had canonised specific forms of psychological motivation as indicators at the crossroads of human choice. What he argued, however, was that such indicators only lead us deeper into the labyrinths and blind alleys of reason.

Instead of borrowing his example from Augustine, Pascal quotes from Montaigne Varro's famous calculus of philosophical sects based on the many candidates for the summum bonum. ${ }^{77}$ Yet Pascal stands much closer to Augustine than to Montaigne. Indeed, the passage in his own work that discusses the philosophical search for the souverain bien immediately leads to an exposition of man's Fall, since no knowledge of the véritable bien can be had without some idea of man's véritable état. ${ }^{78}$ Pascal's problem with the philosophical enterprise of trying to define and to find man's summum bonum, is that the search for happiness leads us astray and makes us follow ineffectual rules and erroneous beliefs that will only increase our suffering. Not being able to achieve what we want to achieve, and being able to achieve only what we should not want to aspire for, man's state is characterised by the same split aspects of grandeur and bassesse Pascal finds in so many parts of both everyday life and the sciences. $^{79}$

Indeed, true to his scientific way of thinking, Pascal conceives of the Christian religion primarily in terms of the right solution to a specific problem: the problem of man's absurd position. The ineffectiveness of human efforts can elegantly be explained by a hypothesis that all philosophers had overlooked, but which was uniquely included in the hypothetico-deductive model of Christian theory: the notion of man's fallen state. ${ }^{80}$ The Christian position, according to Pascal, is the only alternative that accepts the idea of a fundamental friction between the human will and its abilities, and may thus explain the split charac-

${ }^{77}$ Pascal (as in n. 75), Pensées, §§ 27, 111, and 714; ed. Lafuma §§ 408, 76 and 479; ed. Brunschvicg $\S \S 74,73$, and 74 bis. Varro had calculated that the various interpretations of the summum bonum would lead to a total of 288 philosophical sects. Cf. Augustine, De civitate Dei 19.1. Leibniz would offer the computation as an example of his combinatorial art. Cf. G. W. Leibniz, Dissertatio de arte combinatoria (Leipzig: Fickius and Seuboldus, 1666), pp. 50-51.

${ }^{78}$ Pascal (as in n. 75), Pensées, § 181; ed. Lafuma § 148; ed. Brunschvicg $§ 425$, esp. Quotation from $\S 182$; ed. Lafuma $\S 149$; ed. Brunschvicg $\S 430$.

${ }^{79}$ Cf., for example, Pascal (as in n. 75), Pensées $\S 20$; ed. Lafuma $§ 401$; ed. Brunschvicg $§ 437$ : "Nous sommes incapables de ne pas souhaiter la vérité et le bonheur et sommes incapables ni de certitude ni de bonheur".

${ }^{80}$ Cf., for example, Pascal (as in n. 75), Pensées $§ 17$; ed. Lafuma $§ 398$; ed. Brunschvicg $\$ 525$ : "Les philosophes ne prescrivaient point des sentiments proportionnés aux deux états [etc.]", and especially § 182; ed. Lafuma § 149; ed. Brunschvicg § 430: "Sera-ce les philosophes, qui nous proposent pour tout bien les biens qui sont en nous?", as well as $\S 680$; ed. Lafuma $\S 421$; ed. Brunschvicg $\S 606$ : "Nulle religion que la nôtre n'a enseigné que l'homme naît en péché. Nulle sect de philosophes ne l'a dit. Nulle n'a donc dit vrai". See also § 237; ed. Lafuma § 205; ed. Brunschvicg § 489. 
ter of all human strivings. At the same time, this indicates to what extent Pascal's position is essentially Jansenist, and thus of a theological nature. As he argued on the basis of his reading of Augustine and the latter's biographer Jansenius, only an infinite Being can repair the hiatus between man's wishes and man's powers. ${ }^{81}$ Only God may help us avoid frustration.

This may explain the absence, in the Pensées, of a detailed philosophical or psychological explanation of man's messy mind. Not even in the case of such interesting and typically Pascalian notions as the idea of man's search for divertissement, though it points towards a notion of inauthenticity that links his philosophy to later existentialist ideas, do we find an explanation for the supposed ineffectiveness of man's search for beatitude. Rather, Pascal consistently interprets divertissement simply as a kind of mental distraction, a temporary care or soin for the self, that keeps the human being from having to see and recognise its own condition - above all the Faktizität of its mortality. ${ }^{82}$

As a result, Pascal presents the tension between the philosophical norms and man's real goal in life as a more or less accidental fact: God made it impossible to arrive at the one by means of the other. There is no manifest contradiction between the philosophical motivation and the religious solution as such. At times, Pascal even presents Stoic moral norms as simply too difficult to achieve, ${ }^{83}$ or at least too difficult to achieve without grace. ${ }^{84}$ If one reads his criticism of the beastly aspects of human striving (Bassesse de l'homme jusqu'à se soumettre aux bêtes, jusques à les adorer ${ }^{85}$ ), one would hope to find him thinking that philosophical wisdom itself is something incongruous with human nature. In fact, however, Pascal only affirms the standard Pico-like position regarding man's tendency to slip back to a form of animal existence. Due to the fact that the highest level of wisdom is necessarily missed, philosophical alternatives are tested that effectively degrade man and bring him back to the level of beasts. What, in other words, Pascal reintroduces here, is a simple denunciation of Epicureanism, which, in his case, is linked to an even stronger denunciation of Islamic thought as a fundamentally hedonistic type of religion on account of its promise of virgins in paradise. ${ }^{86}$

Thus, misguided and vain though philosophers may have been, Pascal still accepted their view that there was some moral level that rose above sheer hu-

${ }^{81}$ For the references to Jansenius and Augustine, see Sellier's editorial footnote in Pascal, Pensées (Paris, 1999; as in n. 75), p. 226, note 4.

${ }^{82}$ Pascal (as in n. 75), Pensées § 171; ed. Lafuma § 139; ed. Brunschvicg § 143, and especially § 102; ed. Lafuma § 68; ed. Brunschvicg § 205.

${ }^{83}$ Pascal (as in n. 75), Pensées $\S 133,177$ and 179; ed. Lafuma $\S \S 100,144$ and 146; ed. Brunschvicg $\S \S 467,360$ and 350, respectively.

${ }^{84}$ Pascal (as in n. 75), Pensées $§ 174$; ed. Lafuma § 141; ed. Brunschvicg $§ 466$.

${ }^{85}$ Pascal (as in n. 75), Pensées § 86; ed. Lafuma § 53; ed. Brunschvicg § 429.

${ }^{86}$ Pascal (as in n. 75), Pensées § 182; ed. Lafuma § 149; ed. Brunschvicg § 430: "Ceux qui nous ont égalés aux bêtes et les mahométans, qui nous ont donné les plaisirs de la terre pour tout bien même dans l'éternité, ont-ils apporté le remède à nos concupiscences?" See also § 251; ed. Lafuma § 218; ed. Brunschvicg § 598. 
man vanity. ${ }^{87}$ In comparison, Thomas Hobbes' attack on philosophical wisdom was of an even more radical type.

\section{DENIAL}

Based on a theology that questioned whether religion and philosophy were in the same league, Pascal's position was a moderate one compared to the view that saw no logic in moral philosophy as such and altogether refused the notion of mental fruits to be gained on the road to virtue. There is, however, an interesting similarity between Hobbes' and Pascal's forms of pessimism. True to the Augustinian practice of attributing all human natural motivation to philautia, Pascal would state in the Pensées:

Concupiscence and Violence are the Sources of all of our Actions, merely Human. From the former arise those which are voluntary; and those which are involuntary from the latter. ${ }^{88}$

As far as man himself was concerned, there was no limit to his egoism. In his straightforward statement, however, that "of the voluntary acts of every man, the object is some Good to himself, ${ }^{89}$ Hobbes seems to have taken up arms against the prevalent philosophico-religious optimism in a way that defied even the most radical Calvinist.

Indeed, Hobbes' radicalisation of self-love marks a break with the social aspect evident in all of the more optimistic positions within early-modern moral philosophy. Whether we take Pico's view, who saw in Moses' political order the ideal expression of a system based on philosophical initiation and the cleansing of the soul ${ }^{90}$ Walaeus' idea that in civil life, in family life and in private life, ethical norms differentiated human society not only from that of beasts, but from a society of criminals, too $;{ }^{91}$ Geulincx' view that "Friendship with Virtu-

${ }^{87}$ Cf. Pascal (as in n. 75), Pensées § 519; ed. Lafuma § 626; ed. Brunschvicg § 462: "Le commun des hommes met le bien dans la fortune et dans les biens du dehors, ou au moins dans le divertissement. Les philosophes ont montré la vanité de tout cela, et l'ont mis où ils ont pu".

${ }^{88}$ Pascal (as in n. 75), Pensées § 131; ed. Lafuma § 97; ed. Brunschvicg § 334. Translation from [Blaise] Pascal, Thoughts on Religion, and Other Subjects, ed. B. Kennet (London, 1704), p. 293.

${ }^{89}$ Thomas Hobbes, Leviathan: Or, The Matter, Forme, and Power of a Commonwealth, Ecclesiasticall and Civil, Part I, Chapter 14, in The English Works of Thomas Hobbes of Malmesbury, ed. Sir William Molesworth, vol. 3 (London, 1839), p. 120; Thomas Hobbes, Leviathan, ed. C. B. Macpherson (Harmondsworth, 1981), p. 192.

${ }^{90}$ Pico della Mirandola (as in n. 29), De hominis dignitate, Opera omnia, p. 319; ed. Garin, pp. 120 and 122.

${ }^{91}$ Walaeus, Compendium (as in n. 47), sigs. $\nmid 2 \mathrm{v}-\uparrow 3$. 
ous Men" is one of the rewards of virtue besides "Friendship with God"; 92 Spinoza's political notion of "right religion", which is based on the proposition that "[the] good which everyone who seeks virtue wants for himself, he also desires for other men"; ${ }^{93}$ or the more obvious identifications of piety and virtue that we find in Erasmus and Coornhert - all of these authors show a concern with the social side-effect of philosophico-religious growth that is completely lost in Hobbes.

Hobbes' straightforward denial of the idea that social unification is enhanced by the development of a moral stance conflicts not only with the view of most of his contemporaries, but also with ancient philosophical positions. Plato's contention that, for the ideal Republic, it is the type of education that counts; Aristotle's view that the wise man is justly praised for his moral excellence; Stoicism's emphasis on what is intrinsically honestum; and even the Epicurean belief that ataraxia rests partly on the benefits of social life - all of these considerations are absent from Hobbes' reduction of all human desires to egoistic drives. An author like Machiavelli might still represent a classical position in as far as he takes into account the emotional outcome of a certain behaviour. Valla, too, saw in a tyrant's miscalculations the Epicurean source of his mental unease. ${ }^{94}$ Classic discussions between the Stoic and the Epicurean views had focused on the question, to what extent it was necessary to reform one's natural inclinations in order to arrive at the highest level of personal contentment. Arguing that there was never such a thing as a spiritual bonus on moral conduct, let alone a form of beatitude that accompanies our pious and moral ways, Hobbes, on the other hand, totally disconnected social behaviour from mental effect.

Instead, a Common-wealth, according to Hobbes, is never formed by nature, but only "by Institution", since "our naturall Passions" only "carry us to Partiality, Pride, Revenge and the like". ${ }^{95}$ Not only is the early-modern bond between philosophy and religion thereby dissolved, but so too are the humanistic ties that had linked early-modern philosophy to the philosophy of the ancients. Denying that there is such a thing as a mental compensation for higher moral objectives, Hobbes even expressly blamed the ancients for having introduced such a fantasy notion:

To which end we are to consider, that the Felicity of this life, consisteth not in the repose of a mind satisfied. For there is no such Finis ultimus (utmost ayme), nor

${ }^{92}$ Geulincx (as in n. 54), Opera philosophica, vol. 3, pp. 128-130; Ethics, pp. 137139. See also "The Accidental Reward", Opera philosophica, vol. 3, pp. 131-132; Ethics, pp. 139-141.

${ }_{93}^{93}$ Spinoza, Ethica IV, 37. Translation from Curley (as in n. 2), p. 218.

${ }^{94}$ Examples may be found in Lorenzo Valla, De voluptate, sive de vero bono II, XVI,1; XXII, 1-2; XXIII, 1; XXVI, 13-15; in the modern edition of P. M. Schenkel, Von der Lust oder Vom wahren Guten; De voluptate sive De vero bono (Munich, 2004), pp. 174176, 186-188, 190 and 204, respectively.

${ }^{95}$ Hobbes (as in n. 89), Leviathan, Part II, Chapter 17 and 18. Quotations from The English Works, pp. 159 and 153-154, respectively; ed. Macpherson, pp. 228 and 223. 
Summum Bonum (greatest Good), as is spoken of in the Books of the old Morall Philosophers. ${ }^{96}$

If we are to understand the development of moral philosophy in the early modern period and the impact of pagan philosophy on Renaissance thought, it is essential to see that Hobbes' position was not directed against any one of the ancient schools in particular. Rather, it should be read against the background of a conception that, although it was based on "the Books of the old Morall Philosophers", had in fact spread throughout the philosophical systems of his contemporaries. What had become almost universally accepted and was now presented as something all ancient philosophers had actually agreed upon, was the idea that virtue went accompanied by some spiritual pleasure and that there were mental compensations for moral continence.

\section{CONCLUSIONS}

Early-modern moral philosophy had been very consistent in its claim that it paid to be virtuous. If the historical period from Erasmus to Spinoza saw as many different positions in moral philosophy as any other period, beatitudoinspired forms of self-management nevertheless formed a very prominent theme. Educated early moderns were well versed in the idea that there was a psychological dividend on their abstention from lower pleasures, and that human dignity demanded the kind of transformation typically described in the part of ethics that Arnold Geulincx would call "monarchics"97 - the part that primarily concerned itself with the cognitive and spiritual development of the individual and the philosophical goal of attaining the right mental attitude to life, rather than with social rules or ethical maxims. Moral education started with the reform of the moral persona.

Even when philosophy itself underwent remarkable changes, moral philosophers continued to argue that there was a higher-than-ordinary type of felicity awaiting those who kept on the right track on the road to virtue. Accepting the idea that a redirection of mental energy was not only possible, but fruitful to the individual, sixteenth- and seventeenth-century moralists eagerly appropriated classical ideals, and advocated the development of "masculine" reserve and of "virtue" as effective forms of psychological empowerment within their own, Christian, tradition. Yet if the idea of a moral felicitas had already been advocated in classical philosophy, the early-modern context brought with it not only the idea that the aims and the effects of God and Reason were the same and that a sincere lover of God would elicit God's love in return; it also ushered in a new set of issues that did not fit the classical discussions. Shedding doubt on the view that moral training was mentally attractive, dissidents like Pascal

\footnotetext{
${ }^{96}$ Hobbes (as in n. 89), Leviathan, The English Works, p. 85; ed. Macpherson, p. 160.

${ }^{97}$ Geulincx (as in n. 54), Opera philosophica, vol. 3, p. 240; Ethics, p. 264.
} 
and Hobbes formulated their views in counterpoint to the general sentiment. As a result, the dividing lines in early-modern moral philosophy were very different from those most prominent in ancient times - less, that is, along the lines of competing philosophical schools, all of which brought forth their own definition of the summum bonum, and more along the lines of a support for, or a rejection of, the belief in a moral beatitude. Given the widespread philosophical optimism, doubts such as those voiced by Pascal and Hobbes no longer called for an alternative philosophical notion of man's highest good, but for a more radical alternative - an exclusively religious position in Pascal's case and a basically anti-philosophical view in the case of Hobbes.

If, thus far, we have not said much about Christian humanism, this is because the type of theoretical friction that we have been scrutinising, though it is linked to Christian humanism in the stricter sense of the word (the combination, that is, of humanist engagement and religious reform as personified in Erasmus $^{98}$ ), it is only accidentally linked to Christian humanism in the broader sense - the tradition that supplied it with scholarly tools and pedagogical force. Indeed, while Pascal confronted philosophy's high demands with the idea that human moral potentials were severely limited, and Hobbes granted human selflove inalienable rights of its own, they did so in ways closely related to contemporary views on the interconnectedness of philosophy and religion, but quite independently of the project of humanism as such. A humanist pedagogue might all the while keep a more unproblematic view of bettering his fellow men on the basis of literary examples and, following Agricola's advice, maintain a Ciceronian preference for the more charitable and humane philosophies of the Ancient Academy and the Peripatetics, for instance, as against the vain ideas of "the Epicureans, who are content with the insignificant", or "the gruesome rigour of the Stoics". 99

The tendency within moral theory, however, was to go beyond such purely classical debates. Fuelling the philosophical quest that promised some ultimate conceptual grasp of the good life, humanist learning may have contributed to the awakening of rival theories that shed doubt on the attainability and even the desirability of these high-flying philosophical aims. Yet from the standpoint of Christian humanism in the broader sense of the word, these consequences were of an accidental nature. They involved new and rather ideological developments if seen from the original humanist perspective. Hobbes' denial that there was anything pleasurable in making a moral choice was a far cry indeed from the Renaissance view that saw moral development as an integral part of human

${ }^{98}$ For an account of this stricter interpretation of "Christian humanism" as a movement that combined "Italianate classical interests with reforms that addressed [the] longing for both personal spiritual renewal and reform of the church", and Erasmus' role in this movement, see C. G. Nauert, "Rethinking "Christian Humanism"”, in Interpretations of Renaissance Humanism, ed. A. Mazzocco (Leiden, 2006). Quotation from p. 159.

${ }^{99}$ Rudolphus Agricola, In laudem philosophiae, in: Lvcvbrationes aliqvot lectv dignissimae (Cologne: Ioannes Gymnicus, 1539); Opuscula orationes epistulae (Frankfurt am Main, 1975), pp. 155-156. Translation HvR. 
education in general. As Cicero had Piso argue in De finibus, learning was a natural and self-sufficient activity - a view to which the Stoic character Cato was just as willing to subscribe:

Acts of cognition [...] we consider meet to be adopted for their own sake, because they possess an element that so to speak embraces and contains the truth. This can be seen in children, whom we may observe to take pleasure in finding something out for themselves by the use of reason, even though they gain nothing by it. ${ }^{100}$

The kinds of pessimism we find in such authors as Pascal and Hobbes were voices from a different world - preludes to a modern perspective.

${ }^{100}$ Cicero, De finibus bonorum et malorum 3.5.17. Translation from Cicero, On Ends, ed. H. Rackham (Cambridge, Mass., 1914), p. 235. Piso's position can be found in Book 5.15 and 20-22 esp. 